\title{
ANALISIS PESAN DAKWAH SEMBILAN PILAR PERADABAN DUNIA THORIQOH QODIRIYAH NAQSYABANDIYAH PONDOK PESANTREN SURYALAYA - SIRNARASA
}

\author{
Eunis Khoerunnisa, Ridwan Alpian \\ Komunikasi Penyiaran Islam STID Sirnarasa
}

eunis@stidsirnarasa.ac.id

\begin{abstract}
ABSTRAK
Thoriqoh Qodiriyyah Naqsyabandiyyah (TQN) Pondok Pesantren Suryalaya-Sirnarasa sebagai salah satu jawiyah spiritual yang mu'tabar mempunyai way of life dan sebuah belief system berupa Tanbih, sebagai salah satu pedoman dalam mengamalkan, mengamankan dan melestarikan ajaran Thoriqoh Qodiriyyah Nasyabandiyyah (TQN) Pondok Pesantren Suryalaya-Sirnarasa. Syeikh Muhammad Abdul Gaos Saefulloh Maslul QS (Abah Aos) Silsilah ke-38 sebagai penerus kemursyidan Syeikh Ahmad Sohibul Wafa Tajul 'Arifin QS (Abah Anom) Silsilah ke-37 Thoriqoh Qodiriyyah Naqsyabandiyyah (TQN) Pondok Pesantren Suryalaya-Sirnarasa, merinci dan mengambil intisari kandungan dari Tanbih, yang dinamakan "Sembilan Pilar Peradaban Dunia", sebagai pesan dakwah dalam mengamalkan, mengamankan dan melestarikan ajaran Thoriqoh Qodiriyyah Naqsyabandiyyah (TQN) Pondok Pesantren Suryalaya-Sirnarasa. Oleh karena itu maka munculah masalah yang penulis anggap menarik untuk dijadikan sebuah kajian. Pertama mengkaji dan menganalisis pesan dakwah sembilan pilar peradaban dunia thoriqoh qodiriyah naqsyabandiyah pondok pesantren suryalaya-sirnarasa. Metode yang digunakan dalam penelitian ini adalah metode analisis isi. Analisis isi (content analysis) adalah penelitian yang bersifat pembahasan mendalam terhadap isi suatu informasi tertulis atau tercetak dalam media massa. Pelopor analisis isi adalah Harold D. Lasswell, yang memelopori teknik symbol coding, yaitu mencatat lambang atau pesan secara sistematis, kemudian diberi interpretasi. Analisis pesan dakwah dalam sembilan pilar peradaban dunia thoriqoh qodiriyah naqsyabandiyah pondok pesantren suryalaya-sirnarasa meliputi: Butir 1 Mendorong ikhwan dan akhwat untuk memiliki sikap tawadhu, taraahum, tawa'ad dan ta'atuf, Butir 2 Mendorong ikhwan dan akhwat untuk memiliki sikap tawadhu dan menjauhi sikap takabbur, Butir 3 Mendorong ikhwan dan akhwat untuk memilki sikap tulus, rendah hati, setia, berpikir positif, ceria, bertanggung jawab, percaya diri, berjiwa besar, santai dan empati, Butir 4 Mendorong ikhwan dan akhwat untuk memiliki sikap syukur dan rasa kepekaan sosial, Butir 5 Mendorong ikhwan dan akhwat untuk memiliki sikap menghormati ulama, Butir 6 Mendorong ikhwan dan akhwat untuk menjauhi sikap sombong dan bangga diri, Butir 7 Mendorong ikhwan dan akhwat untuk memiliki sikap toleransi dan menjauhi sikap tajassus, Butir 8 Mendorong ikhwan dan akhwat untuk memiliki sikap istiqomah, Butir 9 Mendorong ikhwan dan akhwat untuk memiliki rasa kasih sayang menyayangi.
\end{abstract}

Kata kunci: pesan dakwah, Thoriqoh Qodiriyah Naqsyabandiyah Pondok Pesantren Suryalaya Sirnarasa 


\section{ABSTRACT}

Thoriqoh Qodiriyyah Naqsyabandiyyah (TQN) Pondok Pesantren Suryalaya-Sirnarasa as one of the spiritual jawiyah that mu'tabar has a way of life and a belief system in the form of Tanbih, as one of the guidelines in practicing, securing and preserving the teachings of Thoriqoh Qodiriyyah Nasyabandiyyah (TQN) Pondok Suryalaya-Sirnarasa. Sheikh Muhammad Abdul Gaos Saefulloh Maslul QS (Abah Aos) 38th genealogy as the successor of the martyrdom of Sheikh Ahmad Sohibul Wafa Tajul 'Arifin QS (Abah Anom) 37th genealogy Thoriqoh Qodiriyyah Naqsyabandiyyah (TQN) Pondok Pesantren Suryalaya-Sirnaris, content from Tanbih, which is called "Nine Pillars of World Civilization", as a message of da'wah in practicing, securing and preserving the teachings of Thoriqoh Qodiriyyah Naqsyabandiyyah (TQN) Pondok Pesantren Suryalaya-Sirnarasa. Therefore, there is a problem that the author considers interesting to be used as a study. First study and analyze the message of da'wah of the nine pillars of world civilization thoriqoh qodiriyah naqsyabandiyah pondok pesantren suryalaya-sirnarasa. The method used in this study is the method of content analysis. Content analysis is a study that is in-depth discussion of the content of a piece of information written or printed in the mass media. The pioneer of content analysis was Harold D. Lasswell, who pioneered the symbol coding technique, which is to record symbols or messages systematically, then interpreted. Analysis of da'wah message in the nine pillars of world civilization thoriqoh qodiriyah naqsyabandiyah boarding school suryalaya-sirnarasa includes: Item 1 Encouraging brothers and sisters to have tawadhu attitude, taraahum, tawa'ad and ta'atuf, Item 2 Encouraging brothers and sisters to have tawadhu attitude and stay away from arrogance, Item 3 Encourage brothers and sisters to have a sincere, humble attitude, loyal, positive thinking, cheerful, responsible, confident, big-hearted, relaxed and empathetic, Item 4 Encourages brothers and sisters to have an attitude of gratitude and a sense of social sensitivity, Item 5 Encourages brothers and sisters to have an attitude of respect for scholars, Item 6 Encourages brothers and sisters to stay away from arrogance and pride, Item 7 Encourage brothers and sisters to have an attitude of tolerance and stay away from tajassus attitude, Item 8 Encourage brothers and sisters to have istiqomah attitude, Item 9 Encourage brothers and sisters to have a sense of love.

KEY WORDS: preaching message, Thoriqoh Qodiriyah Naqsyabandiyah Pondok Pesantren Suryalaya - Sirnarasa

\section{PENDAHULUAN}

Sebagaimana kita ketahui, bahwa Islam tersebar ke berbagai belahan dunia ini karena adanya suatu kegiatan dakwah yang dilakukan oleh Nabi Muhammad SAW dan dilanjutkan oleh para sahabatnya. Karena Nabi Muhammad SAW sebagai Nabi terakhir yang bertugas menyampaikan ajaran kepada umat manusia untuk mengikuti agama Islam dengan memberi suri tauladan yang baik. Sebagaimana firman Allah dalam Q.S Al-ahzab : 21 :

\section{لقد كان لكم في رسول الله اسوة حسنة لمن كان يرجو الله واليوم الأخر وذكر الله كثيرا}

Artinya :"telah ada pada (diri) Rasulullah itu suri tauladan yang baik bagimu (yaitu) bagi orang yang mengharap (rahmat) Allah dan (kedatangan hari kiamat dan dia banyak menyebut Allah".

Dakwah Nabi Muhammad SAW agar agama Islam ini bisa diterima oleh umat sekitarnya tidaklah mudah, dan mendapatkan pengikut yang lumayan banyak itu butuh perjuangan. Nabi bersama para sahabatnya mendapat tantangan dan rintangan yang tidak kecil, terutama ketika berdakwah diperiode awal masa kenabian. 
Dalam menghadapi sikap yang tidak bersahabat, Nabi Muhammad SAW tetap mantap dan semakin giat dalam melaksanakan dakwah, perlakuan yang tidak bersahabat yang diterima oleh Nabi Muhammad SAW dibalas dengan penuh kebaikan dan akhlak yang mulia, sebagaimana firman Allah SWT dalam Q.S Al-qalam : 4 :

و انك لعلى خلق عظيم

Artinya : "Dan sesungguhnya kamu benar-benar budi pekerti yang agung”.

Tafsirnya : "Allah telah menjadikan engkau mempunyai rasa malu, mulia hati, pemberani, pemaaf, penyabar dan segala akhlak yang mulia".

\section{LANDASAN TEORI}

Pesan adalah sesuatu yang disampaikan pengirim kepada penerima. Pesan adalah sesuatu yang bisa disampaikan dari seseorang kepada orang lain, baik secara individu maupun kelompok yang dapat berupa buah pikiran, keterangan, pernyataan dari sebuah sikap.

Pesan yang dimaksud dalam proses komunikasi adalah sesuatu yang disampaikan pengirim kepada penerima. Pesan merupakan seperangkat lambang bermakna yang disampaikan oleh komunikator kepada komunikan. Sementara Astrid mengatakan bahwa pesan adalah ide, gagasan, informasi, dan opini yang dilontarkan seorang komunikator kepada komunikan yang bertujuan untuk mempengaruhi komunikan kearah sikap yang diinginkan oleh komunikator.

Sedangkan dakwah hakikatnya memiliki pengertian secara khusus. Secara etimologi kata dakwah berasal dari bahasa Arab yang bermakna panggilan, ajakan atau seruan. Dalam tata bahasa Arab, kata dakwah merupakan bentuk kata “masdar”dari asal kata دعى - ديدعو (da'a-yad'u) yang artinya memanggil, mengajak, atau menyeru. Kata dakwah sering menjumpai atau dipergunakan dalam ayat-ayat Al-Qur'an dalam firman Allah (Q.S Yunus: 25) :

والله يدعو إلى دار السلام ويهدي من يشاء إلى صراط مستقيم

Artinya : "Allah menyeru (manusia) ke Darussalam (surga) dan memimpin orang yang dikehendakinya kepada jalan yang lurus (Islam)".

Pesan dakwah adalah isi pesan komunikasi secara efektif terhadap penerima dakwah, pada dasaranya materi dakwah Islam, bergantung pada tujuan dakwah yang dicapai sudah menjadi doktrin dan komitmen bahkan setiap muslim wajib berdakwah, baik itu secara perorangan ataupun dengan banyak orang, oleh karena itu dakwah harus terus dilakukan. Pesan dakwah tiada lain adalah Al-Islam yang bersumber dari Al-Qur'an dan Al-Hadits sebagai sumber utama yang meliputi aqidah, syari'ah dan akhlak dengan berbagai macam cabang ilmu yang diperolehnya. Jadi pesan dakwah atau materi dakwah adalah isi dakwah yang disampaikan da'i kepada mad'u yang bersumber dari agama Islam.

\section{Sembilan Pilar Peradaban Dunia}

Syeikh Muhammad Abdul Gaos Saefulloh Maslul QS (Abah Aos) Silsilah ke-38 sebagai penerus kemursyidan Syeikh Ahmad Sohibul Wafa Tajul 'Arifin QS (Abah Anom) Silsilah ke-37 Thoriqoh Qodiriyyah Naqsyabandiyyah (TQN) Pondok Pesantren Suryalaya, merinci dan mengambil intisari kandungan dari Tanbih, yang dinamakan "Sembilan Pilar Peradaban Dunia", sebagai pesan dakwah dalam mengamalkan, mengamankan dan melestarikan ajaran Thoriqoh Qodiriyyah Naqsyabandiyyah (TQN) Pondok Pesantren Suryalaya-Sirnarasa, untuk menjaga Ketahanan Nasional Negara Kesatuan Republik Indonesia, untuk kejayaan agama dan negara serta peradaban dunia. 
Adapun yang dimaksud dengan Sembilan Pilar Peradaban Dunia, yaitu : 1) Terhadap orangorang yang lebih tinggi daripada kita, baik dhohir maupun bathin, harus kita hormati, 2) Terhadap sesama yang sederajat dengan kita dalam segala-galanya jangan sampai terjadi persengketaan, 3)Terhadap orang yang keadaannya dibawah kita jangan menghinakannya, atau berbuat tidak senonoh bersifat angkuh, 4)Terhadap fakir miskin harus kasih sayang, ramah tamah serta bermanis budi, 5) Jangan benci kepada ulama yang sezaman, 6) Jangan menyalahkan ajaran orang lain, 7) Jangan memeriksa murid orang lain, 8) Mesti punya pendirian ketika diganggu orang lain, 9) Harus menyayangi orang yang membencimu.

Seorang ulama ahli tasawuf lebih banyak menggunakan bahasa-bahasa rasa, atau lebih menggunakan kekuatan batinnya dalam menyampaikan suatu pesan kepada orang lain. Sering kali seorang ulama tasawuf menggunakan bahasa-bahasa isyarat untuk menyampaikan pesan tertentu, apalagi kalau lawan bicaranya adalah seorang ulama sufi juga, penyampaian sebuah pesan sering hanya menggunakan kiasan bukan menggunakan bahasa fulgar sebagaimana yang dilakukan ahli hukum/faqih. Pada tataran hukum, sebuah bahasa yang mengandung pesan tertentu haruslah diucapkan dengan bahasa yang jelas karena setiap ucapan yang penting itu memiliki implikasi hukum. Sehingga ketika suatu pesan hanya diucapkan dengan bahasa isyarat/kias maka bisa menyebabkan pesan tersebut tidak memiliki legal standing, tidak memiliki dasar hukum.

\section{METODE PENELITIAN}

Metode penelitian merupakan suatu cara pendekatan penelitian yang digunakan dengan maksud memperoleh data yang tepat untuk menjawab masalah-masalah yang diteliti. Metode yang digunakan dalam penelitian ini adalah metode analisis isi. Analisis isi (content analysis) adalah penelitian yang bersifat pembahasan mendalam terhadap isi suatu informasi tertulis atau tercetak dalam media massa. Pelopor analisis isi adalah Harold D. Lasswell, yang memelopori teknik symbol coding, yaitu mencatat lambang atau pesan secara sistematis, kemudian diberi interpretasi.

\section{HASIL DAN PEMBAHASAN}

\section{Pesan Dakwah Sembilan Pilar Peradaban Dunia}

1. Terhadap Orang-Orang Yang Lebih Tinggi Daripada Kita, Baik Dhohir Maupun Bathin Harus Kita Hormati

Islam sebagai syari'at yang lengkap dan paripurna telah mengajarkan umatnya adab dan tata krama kepada sesama manusia. Yang demikian supaya tercipta keharmonisan dan hubungan yang baik diantara mereka, dan lebih jauh diharapkan dengan keharmonisan ini bisa terwujud komunitas masyarakat yang damai yang melaksanakan ibadah kepada Allah ta'ala dengan sebaik mungkin.

Diantara adab yang diajarkan di dalam Islam adalah menghormati orang yang lebih tua. Jauh-jauh hari Rasulullah shallallahu 'alaihi wasallam telah mewanti-wanti ummatnya akan pentingnya adab yang satu ini, beliau shallallahu 'alaihi wasallam bersabda:

\section{لَيَسنَ مِنَّا مَنْ لَمْ يَرْحَمْ صَفِيرَنَا وَيَعْرِفْ شَرَفَ كَبِيرِنَا}

Artinya :"Bukanlah termasuk golongan kami orang yang tidak menyayangi orang muda diantara kami, dan tidak mengetahui kemuliaan orang-orang yang tua diantara kami" (HR. AtTirmidzy)

Butir yang pertama sangat berkaitan dengan akhlak, karena merupakan suatu keharusan bagi seseorang untuk menghormati yang lebih tinggi dari kita, baik dari ilmunya, usianya dll. 
2. Terhadap Sesama Yang Sederajat Dengan Kita Dalam Segala-Galanya Jangan Sampai Terjadi Persengketaan

Kemudian berakhlak kepada manusia adalah toleransi antaragama, memberikan hak sebagai tetangga, warga negara atau warga agama, ikut terlibat dalam segala hal, tidak ingin menang sendiri, bertanggung jawab atas masalah sosial, tolong menolong, saling memaafkan, saling menghormati, kasih mengasihi, sabar dan menahan diri, adanya konsep persamaan, adil, kreatif, dan dinamis. Butir kedua ini sangat berkaitan dengan akhlak, karena sesama manusia harus saling harga menghargai sehingga tidak timbul persengketaan, bahkan akan menghasilkan persatuan, kesatuan dan keharmonisan.

Islam memiliki konsep yang jelas, bagaimana hidup bermasyarakat yang baik, perhatikan hadits rasul berikut :

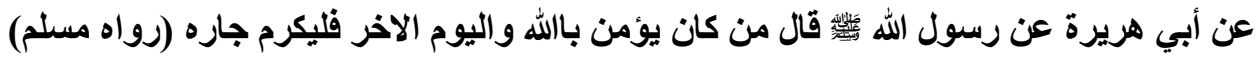

Artinya : "Dari Abu Hurairah ra berkata : Rasulullah SAW bersabda barang siapa beriman kepada Allah dan hari akhir hendaklah memuliakan tetangganya” (HR. Muslim).

3. Terhadap Orang Yang Keadaannya Di Bawah Kita Jangan Menghinakannya Atau Bersifat Tidak Senonoh Bersifat Angkuh

Dalam menjalankan pergaulan sosial, Islam melarang umatnya untuk membeda-bedakan manusia karena hal-hal yang bersifat duniawi, seperti harta, tahta, umur, dan status sosial lainnya. akan tetapi yang terbaik adalah bersikap wajar sebagaimana mestinya sesuai dengan tuntutan ajaran agama dan tidak bertentangan dengan norma-norma kehidupan.

Tidak dapat dihindari, kita juga pasti berkomunikasi dan bergaul dengan orang yang umur dan strata sosialnya lebih rendah dan kita. Kita sama sekali dilarang untuk merendahkan dan meremehkannya.

Kita diperintahkan untuk selalu berusaha menyayangi orang yang umurnya lebih muda dari kita. Rasulullah SAW bersabda:

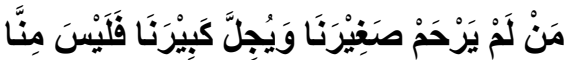

Artinya : "Barangsiapa yang tidak menyayangi orang yang lebih muda di antara kami dan tidak mengerti hak orang yang lebih tua maka dia bukan termasuk golongan kami."( HR Bukhari dalam kitab Adabul Mufrad)

Butir ketiga ini sangat berkaitan juga dengan akhlak, karena manusia dalam pandangan Allah SWT semuanya sama, tidak dibedakan oleh rendah atau tingginya derajat manusia tersebut.

4. Terhadap Fakir Miskin Harus Kasih Sayang Serta Bermanis Budi

Kaya dan miskin adalah dua saudara kembar yang selalu ada dalam setiap tatanan kehidupan. Tidak ada yang bisa di sebut kaya jika tidak ada yang miskin. Seperti halnya pergantian siang dan malam, keadaan kaya dan miskin juga sudah merupakan ketentuan Allah atas diri manusia. Hal yang justru harus lebih ditekankan ialah bagaimana si kaya bisa berbagi dengan si miskin. Sebagaimana firman Allah dalam Al-Qur'an surat An-Nahl : 71 :

والله فضل بعضكم على بعض فى الرزق فما الذين فضلو برادي رزقهم على ما ملكت أيمانهم فهم فيه سواء أفبنعمة الله يجحون

Artinya : "Dan Allah melebihkan sebagian kaum dari sebagian lainnya dalam hal rezeki, tetapi orang-orang yang dilebihkan (rezekinya itu) tidak mau memberikan rezeki mereka kepada budak-budak yang mereka miliki, agar mereka sama (merasakan rezeki itu). Maka mengapa mereka mengingkari nikmat Allah." 
Butir keempat juga sangat berkaitan dengan akhlak, karena manusia tidak di perbolehkan mendiskriminasi seseorang karena melihat dari faktor materinya yang rendah.

5. Jangan Benci Kepada Ulama Yang Sezaman

Para pelajar (santri) tidak akan memperoleh ilmu dan tidak akan dapat mengambil manfaatnya, tanpa mau menghormati ilmu dan ulama. Karena ada yang mengatakan bahwa orangorang yang telah berhasil, mereka ketika menuntut ilmu sangat menghomrati tiga hal tersebut. dan orang orang yang tidak berhasil dalam menuntut ilmu, karena mereka tidak mau menghormati atau memuliakan ilmu dan ulama. Ada yang mengatakan bahwa menghormati itu lebih baik daripada mentaati. Karena manusia tidak di anggap kufur karena bermaksiat, tetapi dia menjadi kufur karena tidak menghormati atau memuliakan perintah Allah SWT.

Rasulullah SAW bersabda:

إن العلماء ورثة الأنبياء، إن الأنبياء لم يورثوا ديناراً ولا درهما، وأورثوا العلم، فمن أخذه؛ أخذ بحظ وافر

Artinya: "Sesungguhnya ulama adalah pewaris para nabi. Sungguh para nabi tidak mewariskan dinar dan dirham. Sungguh mereka hanya mewariskan ilmu maka barangsiapa mengambil warisan tersebut ia telah mengambil bagian yang banyak"(HR. At-Tirmidzi)

Butir kelima memiliki dua penafsiran yang berbeda. Pertama, Rasulullah SAW tidak pernah mengajarkan umatnya untuk saling membenci satu dengan yang lainnya, tetapi beliau menganjurkan untuk saling menyayangi, saling mengasihi dan mengayomi satu sama lain. Dan ini sangat berkaitan dengan akhlak. Kedua, orang yang membenci para ulama sama saja dengan membenci Nabi. Karena sebagaimana dijelaskan dalam hadits di atas, bahwasanya ulama itu adalah pewaris para Nabi. Dan ini sangat erat kaitannya dengan ranah aqidah.

6. Jangan Menyalahkan Ajaran Orang Lain

Kebenaran tunggal adalah kebenaran yang meniscayakan tidak adanya pengakuan terhadapa kebenaran di luar dirinya. Kafir, murtad, dan sesat adalah sederet tuduhan yang kerap terlontar dari satu kelompok kepada kelompok lain, sebagai sebab akibat meyakini kebenaran tunggal tersebut. Dalam sejumlah karyanya, para teolog merumuskan definisi tentang kafir dan iman. Menurut mereka, kafir bermakna pengingkaran terhadap segala sesuatu yang dibawa oleh Nabi Muhammad SAW. Sedangkan iman bermakna kepercayaan terhadap semua kebenaran yang dibawa oleh Nabi Muhammad SAW. Sehingga masing-masing kelompok melemparkan tuduhan kafir terhadap yang lain lantaran dianggap mengingkari ajaran-ajaran yang dibawa nabi.

Allah SWT berfirman dalam Al-Qur'an surat An-Nisa : 59

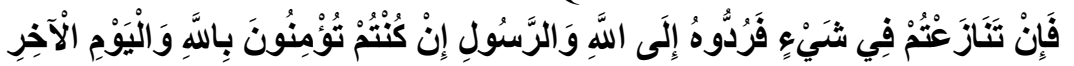

Artinya : "jika kamu berbeda pendapat tentang suatu perkara, maka kembalikanlah kepada Allah dan rosul, jika kamu beriman kepada Allah dan hari kemudian"

Butir keenam masih sangat berkaitan dengan akhlak dan aqidah, karena seseorang tidak boleh merasa bahwa ajarannya/golongannya lah yang paling benar, sehingga menganggap sebelah mata golongan yang lain, yang akhirnya bisa menimbulkan persengketaan dan perpecahan.

7. Jangan Memeriksa Murid Orang Lain

Munculnya pelbagai kelompok atau aliran pemikiran atau bahkan politik yang lengkap dengan nama dan doktrin dogmatisnya masing-masing terjadi di masa para sahabat, tepatnya setelah Nabi wafat. Sejak itulah setiap kelompok sibuk membela kepentingannya masing-masing. Tuduhan demi tuduhan dilontarkan untuk menyingkirkan kelompok pesaing. Di beberapa forum, wakil dari setiap kelompok acapkali bertemu. Tetapi, mereka tidak berdialog mencari solusi untuk menyelesaikan permasalahan umat Muslim secara keseluruhan, justu perdebatanlah yang dikembangkan, yakni perdebatan yang disemangati fanatisme kelompok. 
Allah SWT berfirman dalam Al-Qur'an surat Al-Hujurat : 12 :

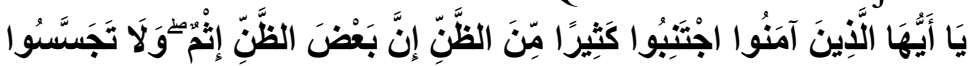

Artinya : "Hai orang-orang yang beriman, jauhilah kebanyakan berprasangka, karena sesungguhnya sebagian tindakan berprasangka adalah dosa dan janganlah kamu mencari-cari kesalahan orang lain."

Butir ketujuh masih sangat erat kaitannya dengan akhlak, karena seseorang tidak boleh mencampuri urusan orang lain, yang akhirnya bisa menimbulkan prasangka buruk sesama manusia. Sedangkan prasangka yang buruk itu merupakan perbuatan dosa.

\section{Mesti Punya Pendirian Ketika Diganggu Orang Lain}

Setiap orang yang beriman pasti akan diuji oleh Allah. Ujian yang Allah turunkan merupakan ajang pembuktian atas keimanan yang telah diikrarkan seseorang. Ujian yang diberikan sangatlah beragam. Ada yang mengenai dirinya, keluarganya, atau harta bendanya. Jenis dan kadar ujian yang akan ditimpakan pada seseorang mutlak merupakan keputusan Allah, semua hanya Allah yang menentukan. Meski demikian, janganlah khawatir karena ujian ini hanya merupakan momen pembuktian keimanan kita kepada-Nya. Allah SWT berfirman dalam Al-Qur'an surat Fushhilat ayat 30 :

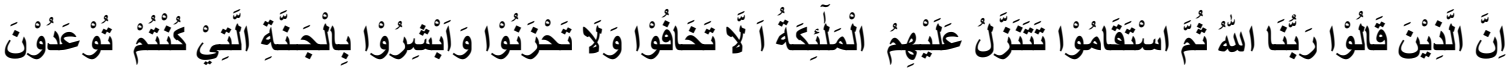

Artinya : "Sesungguhnya orang-orang yang berkata, Tuhan kami adalah Allah kemudian mereka meneguhkan pendirian mereka maka malaikat-malaikat akan turun kepada mereka (dengan berkata), Janganlah kamu merasa takut dan janganlah kamu bersedih hati; dan bergembiralah kamu dengan (memperoleh) surga yang telah dijanjikan kepadamu."

Butir yang kedelapan ini berkaitan dengan akidah, karena seseorang harus mempunyai iman yang kuat, supaya tidak mudah terpengaruh oleh bisikan-bisikan/hasutan-hasutan yang datang kepada dirinya.

9. Harus Menyayangi Orang Yang Membencimu

Allah menciptakan manusia sebagai mahluk sosial bukanlah hanya kebetulan semata tanpa mengandung hikmah didalamnya. Interaksi kepada sesama, dengan segala perbedaannya, menjadi salah satu jalan bagi orang-orang beriman untuk beramal dan mendapatkan keridhoan Allah swt. Rasulullah saw. sebagai suri tauladan terbaik bagi umat manusia telah memberikan contoh bagaimana seharusnya seorang manusia memperlakukan manusia yang lainnya.

Saling sayang menyayangi haruslah menjadi identitas diri, lebih-lebih pada setiap orang yang mengaku dirinya muslim. Kasih sayang tidak terbatas oleh warna kulit, usia, jenis kelamin, ataupun ideologi. Bahkan, rasa kasih itu juga harus diberikan kepada orang-orang yang membenci diri kita.

Allah SWT berfirman dalam Al-qur'an surat Asy-Syuura : 43 :

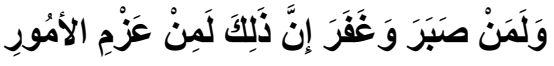

Artinya : "Tetapi orang yang bersabar dan memaafkan sesungguhnya (perbuatan) yang demikian itu termasuk hal-hal yang diutamakan."

Butir yang kesembilan ini sangat berkaitan dengan akhlak, karena kebanyakan manusia tidak bisa mengendalikan hawa nafsunya, bilamana ada orang yang menyakiti dirinya, sehingga menimbulkan rasa dendam di dalam hatinya kepada orang tersebut, yang mana itu akan merugikan bagi dirinya dan orang tersebut. 


\section{Analisi Pesan Dakwah Sembilan Pilar Peradaban Dunia}

1. Terhadap Orang-Orang Yang Lebih Tinggi Daripada Kita, Baik Dhohir Maupun Bathin Harus Kita Hormati

Manusia itu terdiri atas jasmani dan ruhani, yang harus dipenuhi kebutuhannya dan dipelihara stabilitasnya secara seimbang. Manusia sering mengisi dan mengasah otak kita dengan ilmu pengetahuan, tapi melupakan ruhani dengan siraman ruhani (agama), baik aqidah, ibadah, maupun akhlak. Padahal manusia disebut insan karena ruhaninya, bukan jasmani semata.

Ada beberapa faktor yang menyebabkan manusia menolak kebenaran dan bersikap takabur (sombong) kepada manusia lain :

a. Pengaruh harta kekayaan. Tokoh yang ditampilkan dalam Al-Qur'an adalah Qarun. Sebagaimana dijelaskan dalam Al-qur'an surat Al-Qashash : 76 :

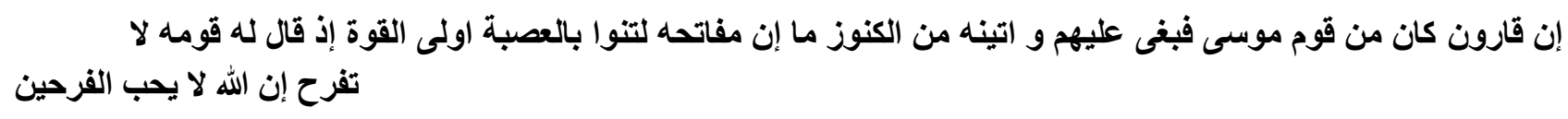

Artinya : "Sesungguhnya Qarun termasuk kaum musa, tetapi dia berlaku zalim terhadap mereka, dan kami telah menganugerahkan kepadanya perbendaharaan harta yang kunci-kuncinya sungguh berat dipikul oleh sejumlah orang-orang yang kuat. (Ingatlah) ketika kaumnya berkata kepadanya, "janganlah engkau terlalu bangga. Sungguh Allah tidak menyukai orang yang membanggakan diri."

b. Pengaruh ilmu pengetahuan, yang diwakili oleh Haman, seorang arsiteknya Fir'aun. Sebagaimana dijelaskan dalam Al-qur'an surat Al-Mu'min : 36-37 :

\section{وقال فرعون يهامن ابن لي صرحا لعلي ابلغ الأسباب * اسباب السموت فأطلع الى اله موسى وإني لأظنه كاذبا}

Artinya : "Dan Fir'aun berkata, "Wahai Haman! Buatkan lah untukku sebuah bangunan yang tinggi agar aku sampai ke pintu-pintu. (yaitu) pintu-pintu langit, agar aku dapat melihat Tuhannya Musa, tetapi aku tetap memandangnya seorang pendusta."

c. Pengaruh kekuasaan, yang di tampilkan oleh Allah dalam Al-Qur'an adalah Fir'aun itu sendiri. Sebagaimana dijelaskan dalam Al-qur'an surat An-Naji'at : 24 :

$$
\text { فقال انا ربكم الأعلى : (Sera) }
$$

Artinya : "(Seraya) berkata, "Akulah tuhanmu yang paling tinggi."

2. Terhadap Sesama Yang Sederajat Dengan Kita Dalam Segala-Galanya Jangan Sampai Terjadi Persengketaan

Ibnu Hajar Al-Asqolani, menukil enam petuah bijaksana dari guru para sufi, agar menjadikan setiap orang yang ditemui menjadi cermin hidup yang baik untuk meningkatkan kualitas moralitas dan integritas diri, yaitu : Apabila engkau bertemu seseorang, katakanlah mungkin dia lebih baik dan lebih tinggi derajatnya di sisi Allah SWT. Pesan ini mendorong untuk tidak meremehkan seseorang meskipun secara tampilan lahiriyah bahkan juga kelakuannya sepintas kurang berkenan.

Apabila engkau bertemu dengan orang yang lebih kecil (muda), katakanlah dia belum berbuat dosa kepada Allah SWT. Bukankah seringkali orang tua under estimate (menilai rendah) kepada anak-anak karena usianya yang muda? Padahal, ilmu dan kearifan tidak selalu melekat dengan usia yang tua. Orang yang muda bisa lebih berilmu dan arif melihat sesuatu. Islam mengajarkan orang tua harus menyayangi yang lebih muda. 
Apabila engkau bertemu dengan orang yang lebih tua, katakanlah dia telah banyak beribadah kepada Allah SWT. Sepatutnya orang yang lebih muda menghormati dan memuliakan orang yang lebih tua. Bukan termasuk seorang muslim yang baik, jika yang muda tidak menghormati yang tua. Masyarakat memandang bahwa orang tua sudah lebih banyak kebaikan dan kontribusinya bagi umat, tentu membuat kita hormat kepadanya dan berupaya untuk mengikuti langkahnya yang baik itu.

Apabila engkau bertemu dengan orang yang berilmu (alim), katakanlah dia telah diberikan anugerah yang belum aku dapatkan, mengetahui apa yang belum aku ketahui dan mengamalkan ilmunya. Orang yang muda akan dituakan (dibesarkan) karena ilmunya. Sementara orang tua akan dikecilkan karena tidak berilmu. Jangan mencari-cari kesalahan dan kekurangannya untuk menjadi alasan tidak perlu belajar kepadanya.

Apabila engkau bertemu dengan orang bodoh, katakanlah dia durhaka kepada Allah karena kebodohannya, sementara aku berbuat dosa dengan pengetahuanku. Memang paling mudah meremehkan orang bodoh, yang tidak pernah mengenyam pendidikan sekolah dan tidak terpelajar. Sementara orang yang berpendidikan tinggi seakan paling terhormat dan patut dihormati. Bukankah tindakan buruk yang merugikan orang banyak justru dilakukan oleh orang berilmu (white crime)? Korupsi dan kemaksiatan sosial dan politik, hampir semuanya dilakukan oleh seorang terpelajar.

Apabila engkau bertemu dengan orang kafir (kufur), katakanlah mungkin aku juga bisa kafir sehingga berakhir dengan amal yang jelek. Orang sholih beum tentu berakhir dengan kesholihan. Begitu pun orang durhaka (ahli maksiat) belum tentu berakhir dalam kemaksiatan. Pada akhirnya, seseorang tidak akan pernah tahu ujung dari perjalanan hidup ini. Apakah ketika ajal tiba, hidup berakhir dalam kebaikan atau keburukan?

3. Terhadap Orang Yang Keadaannya Di Bawah Kita Jangan Menghinakannya Atau Bersifat Tidak Senonoh Bersifat Angkuh

Pada zaman sekarang, tidak dipungkiri manusia lebih mementingkan penampilan luarnya. Menjaga penampilan sebaik mungkin dan menarik perhatian. Tetapi di balik penampilan yang halus dan mulus, hati masih bersisik dan tidak lurus. Masih menggunung amarah dan kebencian, masih diselimuti iri dan dengki, keserakahan dan kelicikan, nafsu dan asusila masih membara. Ketika ada yang memberi sesuatu kepada kita, maka secara otomatis kita menilai orang tersebut baik. Namun di lain waktu, tatkala kita membantu seseorang dan hanya mendapat ucapan terima kasih, stempel buruk kita layangkan padanya. Penilaian kita bukanlah kebenaran yang sesungguhnya dan hanya kebenaran palsu. Baik atau buruknya penilaian kita berdasarkan perasaan dan prasangka saja.

Ketika seseorang berbuat hal yang baik, pada awalnya kelihatan sebagai sesuatu hal yang merugikan. Namun percayalah, bahwa dalam kebajikan itu tidak ada yang sia-sia. Karena pada akhirnya akan mendatangkan keuntungan yang tidak terkira. Masalah memang tidak jauh dari hidup manusia. Sebab dunia adalah lautan masalah, dan hidup di dunia harus siap menghadapi segala masalah yang ada. Tidak ada pilihan terbaik dalam hidup ini, yang ada adalah jalani hidup ini sebaik-baiknya dengan menjadi baik, baik kepada sesama manusia maupun dihadapan tuhan.

4. Terhadap Fakir Miskin Harus Kasih Sayang Ramah Serta Bermanis Budi

Dunia modern, dimana kita hidup didalamnya sekarang ini dengan keanekaragaman persoalan yang dihadapi, terjadinya perubahan tata nilai, integritas budaya, kecenderungan menuju arah globalisasi dan aspek-aspek lainnya merupakan konsekuensi logis dari suatu proses pergerakan peradaban dunia. Dampak postitif dan negatif selalu ada. Di dunia birokrasi korupsi semakin menjadi-jadi, dikalangan anak-anak muda narkoba merajalela, pornografi dan pornoaksi semakin 
bebas tanpa ada bisa memberantas, dimana salah satu efeknya adalah ssex bebas di semua kalangan masyarakat dari berbagai kelas, baik masyarakat dari kelas kaya ataupun masyarakat dari kelas miskin, tua ataupun muda, yang masih lajang ataupun yang sudah berumah tangga.

Kemewahan dalam bentuk kekayaan materi, menjadi sesuatu yang sangat didambakan oleh hampir setiap orang, karena memang lingkungan hidup kita sangat mendorong bagi terbentuknya pola pikir yang cinta dunia dan cinta materi (hedonis). Sekarang ini, materi menjadi tolak ukur baik atau buruk, mulia atau tidak mulia, dihargai atau tidak dihargai, untung atau rugi.

Padahal semestinya, jangan melihat baik dan buruk dari perspektif untung rugi secara materi, karena kekayaan materi bukankah hakekat kebaikan, dan kemiskinan materi bukanlah hakekat keburukan. Kebaikan dan keburukan hakekatnya tidak diukur dari seberapa banyak materi yang di dapat, tetapi seberapa kuat kita menapaki jalan hidup ini diatas jalan-Nya, tanpa melihat seberapa banyak materi yang kita dapat. Kesungguhan kita untuk terus berjalan di jalan-Nya itulah tanda kemuliaan dari-Nya.

\section{Jangan Benci Kepada Ulama Yang Sezaman}

Hinaan dan caci maki tidak akan sampai menyakitkan kalau seseorang bisa menganggap itu bukan caci maki dan hinaan, tapi menganggap sebagai mutiara yang indah dan berharga. Yang seseorang perlukan saat menghadapi permasalahan hidup hanyalah bagaimana mengubah sudut pandang.

Teorinya sangat gampang, tetapi dalam pelaksanaannya harus penuh dengan perjuangan. Itulah gunanya seseorang harus menjadikan setiap peristiwa hidupnya apapun itu sebagai pembelajaran. Sehingga setiap peristiwa kehidupan itu bagaikan permata yang akan membuat seseorang itu menjadi kaya raya.

Para pelajar (santri) tidak akan memperoleh ilmu dan tidak akan dapat mengambil manfaatnya, tanpa mau menghormati ilmu dan ulama. Karena ada yang mengatakan bahwa orangorang yang telah berhasil, mereka ketika menuntut ilmu sangat menghomrati tiga hal tersebut. dan orang orang yang tidak berhasil dalam menuntut ilmu, karena mereka tidak mau menghormati atau memuliakan ilmu dan ulama. Ada yang mengatakan bahwa menghormati itu lebih baik daripada mentaati. Karena manusia tidak di anggap kufur karena bermaksiat, tetapi dia menjadi kufur karena tidak menghormati atau memuliakan perintah Allah SWT.

6. Jangan Menyalahkan Ajaran Orang Lain

Salah satu ciri teologi klasik dari semua aliran tanpa terkecuali adalah meyakini kebenaran tunggal. Maksudnya, setiap aliran hanya mengakui kebenaran sendiri-sendiri dan menyalahkan kebenaran aliran lain. Para teolog klasik berasumsi, adalah tidak logis jika ada kebenaran lebih dari satu. Sebab, hal itu hanya akan menimbulkan benturan satu sama lain atau akan mengarah pada paradoksikalitas akut. Ini tidak boleh terjadi, terlebih kalau menyangkut permasalahan yang sangat prinsipil dan fundamental dalam agama, yaitu teologi. Karenanya, menurut para teolog itu, kebenaran hanya satu, dan kelompok yang selamat juga satu. Kelompok inilah yang kemudian disebut al-firqah al-najiyah (kelompok yang selamat), yakni kelompok yang memonopoli kebenaran tunggal.

Kebenaran tunggal adalah kebenaran yang meniscayakan tidak adanya pengakuan terhadapa kebenaran di luar dirinya. Kafir, murtad, dan sesat adalah sederet tuduhan yang kerap terlontar dari satu kelompok kepada kelompok lain, sebagai sebab akibat meyakini kebenaran tunggal tersebut. Dalam sejumlah karyanya, para teolog merumuskan definisi tentang kafir dan iman. Menurut mereka, kafir bermakna pengingkaran terhadap segala sesuatu yang dibawa oleh Nabi Muhammad SAW. Sedangkan iman bermakna kepercayaan terhadap semua kebenaran yang dibawa oleh Nabi 
Muhammad SAW. Sehingga masing-masing kelompok melemparkan tuduhan kafir terhadap yang lain lantaran dianggap mengingkari ajaran-ajaran yang dibawa nabi.

\section{Jangan Memeriksa Murid Orang Lain}

Dalam tradisi ulama Islam, perbedaan pendapat bukanlah hal yang baru, apalagi dapat dianggap tabu. Tidak terhitung jumlahnya kitab-kitab yang ditulis ulama Islam yang disusun khusus untuk merangkum, mengkaji, membandingkan, kemudian mendiskusikan berbagai pandangan yang berbeda-beda dengan argumentasinya masing-masing.

Penguasaan terhadap perbedaan pendapat ini bahkan menjadi syarat seseorang dapat disebut sebagai mujtahid atau ahli dalam ilmu agama. Orang yang tidak memiliki wawasan tentang pandangan-pandangan ulama yang beragam beserta dalilnya masing-masing, belum dapat disebut ulama yang mumpuni di bidangnya.

Dalam mengemukakan berbagai pendapatnya, ulama-ulama Islam terutama yang diakui secara luas kelimuannya, harus mampu menunjukan kedewasaan sikap, toleransi, dan objektivitas yang tinggi. Mereka tetap mendudukan pendapat mereka di bawah Al-Qur'an dan hadits, tidak memaksakan pendapat, dan selalu siap menerima kebenaran dari siapapun datangnya.

Munculnya pelbagai kelompok atau aliran pemikiran atau bahkan politik yang lengkap dengan nama dan doktrin dogmatisnya masing-masing terjadi di masa para sahabat, tepatnya setelah Nabi wafat. Sejak itulah setiap kelompok sibuk membela kepentingannya masing-masing. Tuduhan demi tuduhan dilontarkan untuk menyingkirkan kelompok pesaing. Di beberapa forum, wakil dari setiap kelompok acapkali bertemu. Tetapi, mereka tidak berdialog mencari solusi untuk menyelesaikan permasalahan umat Muslim secara keseluruhan, justu perdebatanlah yang dikembangkan, yakni perdebatan yang disemangati fanatisme kelompok.

Perdebatan memang merupakan ciri utama teologi Islam klasik. Namun, ia tidak bisa dijadikan pendahuluan untuk memasuki pintu gerbang ilmiah yang mencerahkan dan menyempurnakan spirit humanisme umat Muslim. Perdebatan tak ubahnya seperti perang, yang diistilahkan Shadra dengan "harb al-khid'ah" (perang kecurangan). Siapa yang lebih licik dan pintar beragumentasi dan mengolah kata-kata dalam orasinya, dialah pemenangnya. Tanpa sadar ruh dan hati mereka telah mati, jauh dari pengetahuan hakikat akibat tertutup oleh fanatisme. Sebab yang dicari bukanlah kebenaran, tetapi kemenangan.

8. Mesti Punya Pendirian Ketika Diganggu Orang lain

Istiqomah adalah tegak dihadapan Allah SWT atau tetap pada jalan yang lurus dengan tetap menjalankan kebenaran dan menunaikan janji, baik yang berkaitan dengan ucapan, perbuatan sikap dan niat. Istiqomah juga bisa diartikan dengan tidak goncang dalam menghadapi macam-macam problema yang dihadapi dalam kehidupan dengan tetap bersandar dengan tetap berpegang pada tali Allah SWT dan sunnah rasul.

Istiqomah menjadi modal utama untuk meraih kesuksesan dan meraih kemuliaan baik di sisi Allah SWT maupun di sisi manusia. Tanpa beristiqomah niscaya manusia tidak dapat meraih tujuan hidup yang hakiki. Sikap istiqomah menunjukkan kekuatan iman yang merasuki seluruh jiwa, sehingga seseorang tidak akan mudah goyah dan cepat menyerah pada tantangan dan tekanan.

Setiap orang yang beriman pasti akan diuji oleh Allah. Ujian yang Allah turunkan merupakan ajang pembuktian atas keimanan yang telah diikrarkan seseorang. Ujian yang diberikan sangatlah beragam. Ada yang mengenai dirinya, keluarganya, atau harta bendanya. Jenis dan kadar 
ujian yang akan ditimpakan pada seseorang mutlak merupakan keputusan Allah, semua hanya Allah yang menentukan. Meski demikian, janganlah khawatir karena ujian ini hanya merupakan momen pembuktian keimanan kita kepada-Nya.

\section{Harus Menyayangi Orang Yang Membencimu}

Syahdan, Zainal Abidin Ali bin al-Husain pernah dihina orang dalam perjalanannya ke masjid. Tak terima majikannya diperlakukan demikian, beberapa orang pembantunya ingin memukul orang tersebut dan menyakitinya. Namun Zainal Abidin Ali bin al-Husain melarang mereka bertindak seperti itu karena kasih sayangnya terhadap orang tersebut.

Akhlak kasih sayang merupakan akhlak yang terpuji lagi utama yang harus dimiliki seseorang. Keutamaan akhlak kasih sayang ini dapat dipahami dari firman Allah SWT dalam AlQur'an surat Al-Balad : 17 :

\section{ثم كان من الذين امنوا وتواصوا بالصبر وتو اصوا بالمرحمة}

Artinya : "Kemudian dia termasuk orang-orang yang beriman, dan saling berpesan untuk bersabar dan saling berpesan untuk kasih sayang."

Sifat kasih sayang terlahir dari hati yang tipis (sensitif) dan kelembutan jiwa. Hatinya sangat peka terhadap perasaan orang lain dan kelembutan jiwanya mendorongnya untuk memberikan sesuatu yang ia miliki kepada orang lain. Inilah yang menjadikan orang yang memiliki sifat kasih sayang selalu memaafkan kesalahan orang lain, menolong orang yang mendapatkan musibah, membantu orang lemah, memberi makan kepada orang yang lapar, memberi pakaian kepada orang yang telanjang, mengobati orang yang sakit, dan menghibur orang yang sedih.

Agar akhlak kasih sayang dapat menjadi kepribadian dan kebiasaan, salah satu upaya yang harus dilakukan, yakni hendaknya membiasakan diri untuk membeningkan jiwa dan membersihkan hati serta mempraktikannya dalam setiap mengerjakan kebaikan, menjauhi keburukan, dan menghindari kerusakan.

\section{KESIMPULAN}

Berdasarkan hasil penelitian dan pembahasan maka dapat ditarik suatu kesimpulan bahwa Pesan dakwah dalam sembilan pilar peradaban dunia thoriqoh qodiriyah naqsyabandiyah pondok pesantren suryalaya-sirnarasa meliputi pesan dakwah akhlak dan aqidah, yaitu : Butir "Terhadap Orang-Orang Yang Lebih Tinggi Daripada Kita, Baik Dhohir Maupun Bathin Harus Kita Hormati”, berisi tentang akhlak; Butir "Terhadap Sesama Yang Sederajat Dengan Kita Dalam Segala-Galanya Jangan Sampai Terjadi Persengketaan", berisi tentang akhlak; Butir "Terhadap Orang Yang Keadaannya Di Bawah Kita Jangan Menghinakannya Atau Bersifat Tidak Senonoh Bersifat Angkuh", berisi tentang akhlak; Butir "Terhadap Fakir Miskin Harus Kasih Sayang Serta Bermanis Budi”, berisi tentang akhlak;Butir "Jangan Benci Kepada Ulama Yang Sezaman”, berisi tentang akhlak dan aqidah; Butir "Jangan Menyalahkan Ajaran Orang Lain", berisi tentang akhlak dan aqidah.

\section{DAFTAR PUSTAKA}

Abdul Gaos Saefulloh Maslul, Muhammad. 2006. Lautan Tanpa Tepi. Bandung : CV. Wahana Karya Grafika

Abu Zakariya An-Nawawi, Yahya bin Syarif. 1996. Syarah An-Nawawi 'ala Muslim. Daar AlKhoir

Adz-Zahabi, Syamsudin Muhammad bin Ahmad. Mijaanul 'itidal. Daarul Kutub : Beirut 
Ahmad Syafi'i, Agus dkk 2002. Metode Pengembangan Dakwah. Bandung : Pustaka Setia

Al Buny, Jamaluddin Ahmad. 2002. Menelusuri Taman-Taman Mahabbah Shufiyah. Yogyakarta :

Mitra Pustaka

Isa Muhammad bin Surah, Abi. 1994. Sunan Tirmidzi. Beirut : dar al-Fikr

Ismail., 2000. Menjelajah atas Dunia Islam. Bandung : Mizan

Jumantoro, Totok. Psikologi Dakwah. Jawa Barat : Sinar Grafika Offset

Kafi, Jamaludin. 1997. Psikologi Dakwah. Surabaya : Indah

Kamal, Mustafa dkk., 2002. Fiqih Islam. cetakan II Yogyakarta : Citra Karsa Mandiri

Mardani, Akbar. 2015. Kertas Sakti Buat Negara, Tangerang : Arsy Publishing House - RM Books

Shohibul Wafa Tajul 'Arifin, Ahmad. 2005. Miftah Ash-Shudur. Jakarta : PT Laksana Utama

Syukir, Asmuni. 1983. Dasar-Dasar Strategi Dakwah Islam. Surabaya : Al Ikhlas

Tasmara, Toto. 1997. Komunikasi Dakwah. Jakarta : Gaya Media Pratama

Tim Penyusun Studi Islam IAIN Sunan Ampel Surabaya., 2012. Pengantar Studi Islam. Surabaya

Tinongan, Rahman dkk. 1997. Fiqih Ibadah. Jakarta : Gaya Media Pratama

Uchjana Effendy, Onong. 2005. Ilmu Komunikasi Teori dan Praktik. Bandung : Remaja Rosda Karya

Wawancara dengan Syeikh Muhammad Abdul Gaos, Sesepuh Pesantren Sirnarasa Cisirri. Tanggal 10 April 2018. Jam 10. 